\title{
The Degree of Availability of Soft Leadership skills Among government School Female Administrator in Khan Yunis and Their Relationship to the Level of Organizational Happiness in Their Schools
}

\author{
Marwan W. Al-Masry \\ Al-Quds Open University - Gaza - Palestine
}

\section{Abstract}

This research aimed at identifying the degree of availability of soft leadership skills among government school female administrator in Khan Younis Governorate and its relation to their level of organizational happiness in their schools from the point of view of female teachers, by using the descriptive/ correlation approach and referring to previous literature review, a questionnaire was designed consisted of (85) items distributed on (13) axes: Collaboration and Teamwork skill, Communication Skill, Initiative Skill, Leadership Ability, People Development/Coaching Skill, Personal Mastery, Planning and Organizing Skills, Presentation Skills, Management processes, Professional attitude, Communication in the workplace. Dedication. Economic condition, and after verifying its validity and reliability, the questionnaire has been applied to a stratified random sample of (260) female teachers.The study found that the degree of availability of soft leadership skills was "very high" and the level of organizational happiness was "high", it also found a positive correlation relationship to the degree of availability of soft leadership skills among government school female administrator and the level of organizational happiness in their schools.

Keywords: Soft Leadership; Organizational Happiness; Khan Younis Governorate; Government School

Citation: El-Masry, M,. The Degree of Availability of Soft Leadership skills Among government School Female Administrator in Khan Yunis and Their Relationship to the Level of Organizational Happiness in Their Schools, SVU-Journal of abstract 2020, 2 (1): pp1 (retrieved from the SVU- International Journal Of Educational Sciences,2020, No 4)

Copyright: Publisher South Valley University. This is an open access article distributed under the terms of the creative common attribution license, which permits unrestricted use, distribution and reproduction in any medium provided the original author and source are created. 